\title{
Exploring Public Procurement Reforms in Rural Local Authorities in Zimbabwe
}

\author{
Paradzai Munyede \\ College of Peace, Leadership and Governance \\ Africa University, Zimbabwe \\ E-mail: munyedep@africau.edu \\ Jephias Mapuva \\ Bindura University \\ Faculty of Science and Engineering \\ Geography Department, Bindura-Zimbabwe \\ E-mail: mapuva@gmail.com
}

Received: Jul. 28, 2019 Accepted: Aug. 19, 2019 Online published: Jan. 13, 2020

doi:10.5296/jpag.v10i1.15156 ＵRL: https://doi.org/10.5296/jpag.v10i1.15156

\begin{abstract}
It has been noted that prior to the introduction of public procurement reforms, Zimbabwe's procurement system was centralised, vulnerable to corruption, inefficient and bureaucratic. In 2018, the new decentralized public procurement reforms were introduced to address the shortcomings of the previous procurement regime by giving procurement powers to procuring entities. The aim of this paper is to highlight the implications of the reforms in implementation by rural local authorities in Zimbabwe. This paper adopted a qualitative research design with desktop approach being used to review related literature. The findings reveal that the plethora of reforms are a welcome development in public procurement. It has also been noted that there are many challenges militating against rural local authorities' propensity to implement the new set of reforms. These challenges affect the ability of rural local authorities to deliver services timeously to communities thereby retarding realization of sustainable development in rural areas in Zimbabwe.
\end{abstract}

Keywords: public procurement, devolution, decentralisation, re-centralization, bureaucracy, local government, local authorities 


\section{Introduction}

In developing countries public procurement remains as one of the major drivers of economic growth and development, (Tsabora, Public Procurment in Zimbabwe: Law, Policy and Practice, 2014). On the other hand OECD as cited in (Chiappinelli, Decentralization and Public Procurement Performance.New evidence from Italy, 2017) posits that public procurement account for about $15-20 \%$ of GDP of developing economies, thereby making it one of the major expenditure lines. In Zimbabwe public procurement accounts for $20-25 \%$ of the $\$ 4$ billion annual budget, Procurement Regulatory Authority of Zimbabwe (PRAZ) ,(2018).Therefore, it is critical for a government to operate an efficient, transparent and effective procurement system as it will lead to a positive contribution to improved welfare of its citizens.

The ushering in of the new Public Procurement and Disposal of Public Assets Act, chapter 22:23 was applauded as one of the best reforms to the tainted public procurement system in Zimbabwe. The Act discarded the centralized procurement system which was dominated by the then State

Procurement Board by decentralizing procurement to individual public entities. However, despite the fact that individual public organizations are given powers to preside over all procurement functions, there has been challenges with the act as noted by the words of the Chief Executive Officer of the Procurement Regulatory Authority of Zimbabwe when he retorted that, out of the 92 local authorities over 70 translating to $76 \%$ were resisting implementing the new procurement Act.

Further, the Permanent Secretary in the Ministry of Local Government, Public Works and National Housing in his circular dated $29^{\text {th }}$ of November 2018 indicated that most local authorities were not complying with the procurement act and he directed them to comply as a matter of urgency. Some of the challenges in the new set of reforms include unwillingness to fully decentralise procurement function by central government, volatile economic environment, lack of institutional capacity and limited access to information technology. The statement contradicts itself in that, the new Act is purported to empower local governments to do their own procurement, and therefore it defies logic why the same authorities will not embrace the new Act. Therefore, it is pertinent to evaluate the new public procurement act so as to give an informed decision on why there seems to be resistance in the implementation of the Act. Therefore, central to the research is to understand the extent to which the new procurement act has aided or curtailed efficient and transparent procurement by government agencies especially rural local governments.

\section{The Concept and Practice of Public Procurement}

Public procurement can also be defined as the utilization of public funds generated from various sources either public or private for acquisition of goods, consulting and non-consulting services. This definition positions public procurement based on functions performed by public servants when raising public funds and the execution of expenditure. To this end, (Kagune and Wamalwa, 2018) concured when they retorted that in Kenya public 
procurment is the avenue in which revenue raised is expensed for the purpose of delivering public services.In South Africa, (Munzhedzi, 2016) points out that public procurment is not only used to to deliver public services but it als serves as a policy to address historical imbalances of Aparthaid which had a centralised system which was only benefiting a minority group.Therefore, to adderss this anomaly the South African Government adopted a presferential system which ensure that other disadvanged groups benefit.Further the fedral government then decentralised procurment to parasatatals and local governments.

Public expenditure by government constitutes a large portion of public sector budget and public procurement is one of the major expenditure items. The OECD report as cited in (Chiappinelli, 2017) posits that public procurement is both a paramount phenomenon and a leading activity of Government. Another school of thought states that public procurement is the manner in which public institutions acquire their goods and services (Musanzikwa 2013). On the other hand it has been argued that public procurement is an area where public administration and public finance management converge (Tsabora, 2014).

Zimbabwe just like most African countries, have introduced procurement reforms in order to enhance transparency, accountability, competitiveness, fairness, professionalism and cost effective. In Nigeria, the government introduced the public procurement act in 2007, mainly because the centralised system had been embroiled with corruption, red tape and delays in awarding tenders, (Adewole, 2014). Further, Adewole, (2014) highlights that the new procurement act in Nigeria was a pro-active reform to strengthen institutions so that they will be able to deliver services more efficiently and attain quick development in the country. The procurement act applies to the federal government, its regional and local governments, thus bringing congruency in the public sector as the procurement act became the only legislation to regulate all tiers of government. Public procurement progression in Kenya exudes a lot of similaririties with Zimbabwe as it evolved from being non regulated, centralised, constitutionalized and finally enactment of the Public Procurement and Disposal Act of 2005. Kagume and Wamalwa, (2018) posit that public procurement reforms in Kenya where instituted because the centralised system was very corrupt and had become responsive to development of the country. The Public Procurement and Disposal Act in Kenya is used by all tiers of government and it decentralised procurement activities to procuring entities.

The South African experience shows that public procurement evolved from being a centralised, restricted and a privilege for a few white minorities to being constitutionalized in 1996 to remove this segregations and address socio-economic disparities, retorts, (Anthony, 2019). On the same note, (Bolton, 2006) concurs when he stated that in South Africa after 1994, public procurement was remodeled to become a wealth redistribution tool to previously disadvantaged groups. This was trough enactment a plethora of policies which includes Preferential Procurement Policy Framework Act and Municipal Finance Management Act among others. To achieve this development agenda, procurement was then devolved to local governments as this would speed up implementation process as well enhancing transparency and accountability.

In all of the above countries, researchers concurred that public procurement was necessary as 
it is one of the avenues through which government's addresses economic and social challenges affecting communities. The literature also concurred that decentralizing procurement function was a better way speed up procurement process. However, Adewole, (2014 pointed out that there was significant progress in implementing public procurement reforms in central government ministries in Nigeria, however the same reforms where failing to find traction in local governments because of weak institutional capacity, lack of political will and failure to interpret the new laws.

\section{History of Public Procurement in Zimbabwe}

Since 1980 there was no official procurement policy framework in Zimbabwe which laid down the major pillars and technical features till 2013 argues Tsabora (2014). He further noted that due to lack of policy framework, the Minister of Finance in his 2014 National budget, alluded to the fact that there was need to overhaul public procurement in order to promote accountability, value for money, professionalism, transparency and efficiency. This was intended to install business confidence and promote delivery of services by public institutions. Since 1980 when Zimbabwe gained political independence, the procurement system was centralized and very chaotic. Musanzikwa (2013) has described the then Public procurement system in Zimbabwe as opaque especially in the awarding of tenders. In order to address such an anomaly, governments must design and implement sound procurement policies and practices to achieve value for money through transparent, effective and competitive bidding (Chiappinelli 2017). Accordingly, (Musanzikwa 2013) points out that public procurement in Zimbabwe was for long been faced with a myriad of challenges which included delays in awarding of tenders, corruption, political interference and incompetence. Procurement of goods and services was centralized to the State Procurement Board which was responsible for managing and awarding contracts in the country once they exceeded certain thresholds (Chigudu 2014).

The Procurement Act, outlined that the SPB was responsible for conducting procurement on behalf of procuring entities, supervise proceedings of procuring entities and carry out any investigations on procuring entities. However Musanzikwa (2013) noted that the State Procurement Board in Zimbabwe before the reforms was inefficient, bureaucratic and public entities complained of delays in the awarding of tenders. This delay in awarding of tenders has had a direct impact on service delivery as most public projects took long to be completed. Further, the performance of centralized procurement created mistrust in the private sector thereby stifling development. As noted by Tsabora (2014) inefficient and compromised public procurement creates and regenerates corruption, poverty, misuse of public funds and consequently underdevelopment. Therefore, these anomalies caused agitation for decentralization of procurement functions to procuring entities.

In order to reform public procurement in Zimbabwe, the Government then discarded the then Public Procurement Act Chapter (2 of 1999) and replaced it with the Public Procurement and Disposal of Public Assets Act, Chapter (22:23). This was also done to align public procurement laws to section 315 of the constitution of Zimbabwe. The new Act ushered in new changes, which include rebranding of the former State Procurement Board 
(SPB) to Procurement Regulatory Authority of Zimbabwe (PRAZ), decentralization of procurement to procuring entities comprising central government ministries, departments, parastatals and local governments.

The public procurement reforms are a positive development in Zimbabwe, although early indications have shown that the reforms may eventually pose serious challenges in fulfilling intended objectives of speeding up procurement processes which would translate to improved delivery of public goods and services. Research from other countries indicates that public procurement reforms have the potential to bring sustainable development in local communities if they are fully understood and implemented. However, in Zimbabwe with particular reference to rural local authorities, there is little research to show the implications of the new reforms. Therefore, it is the intention of this study to highlight the implications of the new public procurement reforms to rural local authorities in their day-to-day implementation of the public procurement act and regulations.

\section{Local Government and Procurement in Zimbabwe}

In Zimbabwe local governments are constitutional bodies established under chapter 14 of the Constitution of Zimbabwe. Mapuva (2015) points out that local governments are the conduits through which services are provided to communities, therefore their capacitation to carry out tasks becomes paramount. They are two categories of local governments namely Urban Councils and Rural District councils. As posited by (Mushamba, 2010), there are sixty rural district councils and thirty two urban councils to give a total of ninety two local authorities whose powers are outlined under section 276 (1) of the constitution which reads:

Subject to this constitution and any Act of Parliament, a local authority has the right to govern, on its own initiative, the local affairs of the people within the area for which it has been established, and it has all the powers necessary for it to do so.

In order to strengthen capacity of local governments to deliver services, section 264 states that powers and responsibilities must be devolved to lower tiers of government. To this end (Mapuva, 2015) concurs when he pointed out that devolution will benefit local governments as they will cease from depending on delegated powers in their decision making processes. It is therefore, pertinent that for local governments to be able to deliver goods and services promptly to communities, devolution needs to be implemented without hidden agenda by central government.

Further they also derive powers from the Urban Councils Act, Chapter (29:15) and the Rural District Councils Act, Chapter (29:13) respectively .They also administer a plethora of various statutes. Though they are all in the same category as local governments, there are institutional, structural and capacity differences which make it worthwhile to study them independently. In terms of socio economic development Chatiza (2010) noted that the urban local governments are well advanced as compared to rural district councils mainly due to colonial bias as well to its perpetuation by the post independence African government. In relation to rural local authorities (Zimbabwe Institute 2005) noted that: 
The deteriorating macro economic situation has severely compromised decentralisation programmes. Local authorities are failing to collect enough revenue from the poor ratepayers. Borrowing costs from the private sector is prohibitively high. Their revenue base is small and continuously shrinking. There are serious shortages of adequately qualified and experienced staff in the technical and accounting departments of councils.

In the absence of adequate resources, service delivery by local authorities has further deteriorated and this has affected the local authority's ability to take on additional decentralized functions.

From the above it becomes pertinent that rural district councils needs to be analysed on their own not in the umbrella body of local governments in Zimbabwe to understand how the impact of the new procurement.

\section{Methodology}

In order to fully comprehend the procurement challenges being faced by rural local authorities, this study adopted the desktop research approach. Perusal of legal documents, minutes from conferences as print media papers were used to understand the challenges in rural local authorities in Zimbabwe.

\section{Discerning the principle of devolution}

Rondinelli et al (1983) retorts that through decentralisation, countries have managed to produce more efficient and effective administration at local levels by expanding capacities outside the realm of national government. Hartmann, (2008), states that decentralization is the transfer of power, responsibilities and finances from central government to sub-national governments. On the other hand, another school of thought postulates that decentralization is a broad concept whish takes various forms which include devolution, privatization, delegation or deconcentration, Rondinelli at el ,(1983). Accordingly, Mapuva and Miti (2019) pointed out that each of the forms has its own distint features and characteristics. They highlighted that through practice, devolution has seen more success in federal states like Germany, Nigeria and South Africa as compared to unitary states.

Levine and Bland (2010) posit that devolution is the increased reliance upon subnational levels of government with some degree of political autonomy that is substantially outside direct central government control but will be subject to general policies and laws affecting the whole country such as rule of law. On the other hand Faguet (2012) is of the view that devolution is that function which creates or strengthens subnational units of government, the activities of which are substantially outside the control of central government. He further states that local governments are independent, autonomous and have exclusive authority over explicitly reserved functions. On the same subject matter, Rondinelli, (1983) et al asserts that:

devolution is the creation or strengthening--financially or legally--of sub national units of government, the activities of which are substantially outside the direct 
control of the central government. Under devolution, local units of government are autonomous and independent, and their legal status makes them separate or distinct from the central government. Central authorities frequently exercise only indirect, supervisory control over such units.

Proponents of devolution argue that this mode of decentralisation enhances local governance by curtailing red tape as decision making is quicker and effective. They further posit that improved service delivery by local governments is possible as corrective measures to any policy challenges are rectified timeously. It is the aim of this paper highlight that adoption of public procurement reforms in Zimbabwe is a welcome development. However, the paper points that the new public procurement act is not entirely new but it's a replication from other African countries whose institutional and political settings are different from Zimbabwe. The paper analyzes the policy by highlighting that the intended outcomes of the policy are difficult to achieve in rural local governments in Zimbabwe because of various shortcomings.

\section{Legal and regulatory framework}

In order to provide for rules which governs how public procurement has to be done, a legal architecture needs to be in place to act as the agora where procurement activities are done within the prescribed limits. The Constitution of Zimbabwe amendment No. 20 of 2013 section 315 (1) provides that:

An Act of Parliament must prescribe procedures for the procurement of goods and services by the State and all institutions and agencies of government at every level, so that procurement is transparent, fair, honest, cost effective and competitive.

The Constitution therefore provides a broader framework on how procurement is envisaged to be done in Zimbabwe. In order to comply with this constitutional provision the Public Procurement and Disposal of Public Assets Act, Chapter (22:23) was promulgated in 2017.The main objective

of new act was to sanitize the chaos which had characterize public procurement in Zimbabwe .For this reason, OECD (2005) states that, regulatory reforms are necessary to national economies as it provides guidance to market openness, transparency, cost savings and competitiveness. Further, OECD posits that policy reforms is not a once off event but it requires continuous engagement of stakeholders. This was also collaborated by Natural Resources Governance Institute (2015) when it stated that the best designed legislation is anchored on broad consultation and involvement of stakeholders with provision of feedback mechanism to any challenges. It is in view of the above that this paper looks at the public procurement and disposal act to ascertain its impact in rural local governments in Zimbabwe.

\section{A Critical Analysis of the Zimbabwe Public Procurement Act of (2018)}

Before the enactment of the new act, public procurement in rural local authorities was taken 
as an administration function and the procurement committee was composed of heads of departments of the council. However section 17 of the new act prescribes that procuring entities must establish a Procurement Management Unit (PMU) which is a department composed of personnel with relevant procurement qualifications. This move is quite commendable as it brings professionalism to the procurement of goods and services in local governments.

However, most rural district councils in Zimbabwe lack financial capacity to employ a full complement of staff to fill a new department as they already overstaffed and overburdened with outstanding salaries and statutory obligations. As a result of the above ,over the years rural local authorities have been struggling to provide meaningful services to their residents resulting in the Minister of Finance prescribing in his 2017 budget that $70 \%$ of councils budgets must go to service delivery whilst $30 \%$ caters for salaries.

Further, section 18 directs that procuring entities must establish evaluation committee whose function is to evaluate bids and preparation of evaluation bids to the PMU or Accounting officer.

Its membership is composed of other heads of departments who are not members of PMU. Further, another bureaucratic layer is added as a result of section 91 of the Act which directs that a disposal committee must be established to dispose redundant and obsolete public assets. Whilst this might not be a challenge to urban local authorities who in most cases have staff complement of between two hundred up to ten thousand employees, as for rural district councils it's a nightmare as most of them have staff establishment ranging from twenty five to eighty employees.

\section{Sub-District Structures}

In Zimbabwe, local governments have lower substructures, which have autonomy in the management of their administration affairs. Such institutions include schools and clinics. These institutions receive public funds through fees and they incur expenditure according to the guiding policies and regulations without regular supervision by local governments except for audit purposes. The schools and clinics are small institutions with a smaller revenue base and limited staff members. However, according to the new procurement act, they have to comply with the act but in reality they do not have capacity to employ professional staff members to carry out procurement as per the new act.

\section{Multiple documentations and returns}

As part of it powers, section 7 (b) of the act reads:

Without limiting section 5 ("Establishment of Procuring Regulatory Authority of Zimbabwe"),in the exercise of its functions the Authority shall have power, subject to this act, to do any of the following:

(b) To require procuring entities to collect information regarding procurement and to provide the Authority with such information in such form, and at such intervals or within such periods as the Authority may direct 


\section{Mll Macrothink}

Journal of Public Administration and Governance ISSN 2161-7104 2020, Vol. 10, No. 1

This provision does not explicitly state the type of documentation, which are required from procuring entities. This therefore, vests excessive powers within the Procurement Regulatory authority of Zimbabwe such that they will demand anything from local governments at any time thus resulting in procurement overshadowing other core activities in rural local governments. The returns required by PRAZ are an administrative burden and the reporting system creates confusion to local government employees. The insistence of regular reporting to PRAZ rather than to the elected body of councillors will result in council employees becoming more accountable to the wrong body there by usurping legitimate authority of councillors as they will be two competing centres of power which is not ideal. Some of the documentations are as follows;

\section{Procurement Annual plan}

Zimbabwe is a country, which has experienced very volatile economic environment over the last two decades with prices of goods fluctuating at times on a daily basis. The economic environment makes it difficult to implement annual plans as everything is eroded by the failing economy. Whilst planning is key to the success of organizations as it acts as the daily campus, in relation to public procurement in Zimbabwe, preparation and documentation of annual procurement plan the act requires it as a distinct document to be submitted to the Authority as provided by section 22 of the procurement act. This is an additional administrative burden to councils as it adds more paperwork outside the other annual financial budgets they prepare. The act does not provide for a supplementary plan during the year if there are changes. This shows that the act is not coordinated with the volatile, uncertain, complex and ambiguous (vuca) Zimbabwean economy that is very unpredictable. The Zimbabwean economic environment has not been stable for over two decades; therefore there must be room to allow adjustments to plans to take into account these variations.

\section{Monthly and Annual Procurement Plan Return}

Section 7 (b) gives the Authority wider power by stating that through its supervisory functions, the Authority can direct procuring entities to submit certain returns. The major challenge is the deliberate concealing of what constitutes returns, which have to be submitted to the Authority. To illustrate this various circulars issued in 2018 and 2019 by PRAZ directed rural local authorities to submit annual and monthly returns respectively. This might not be the end as the Authority may direct Local authorities to submit quarterly or even fortnightly returns. This provision is open to abuse by the authorities whilst on the hand it adds unnecessary workload to local authorities.

\section{Re-Centralization of procurement function Authorization and Approval of tenders}

The old State procurement Board among its various functions, used to issue out purchasing thresholds under which procuring entities would have to refer to the board if the tenders exceeds a certain threshold and this was highlighted by all government agencies as the source of red tape in prolonging awarding of tenders. The expectations was that this draconian provision was going to be abandoned completely, however, the new procurement act under section 15 states that procuring entities must refer the Special Procurement 


\section{Mll Macrothink}

Journal of Public Administration and Governance

ISSN 2161-7104

2020, Vol. 10, No. 1

Oversight Committee ( SPOC) if a tender has a value above the prescribed threshold. Therefore, there is no difference with the old act but only that there has been cosmetic changes of appointing Chief Executive Officers of rural locals authorities as heads of procuring entities but with curtailed powers. It is also worth to note that the act does not provide for a board to review tenders above certain tender limits therefore it is not clear how Procurement Regulatory Authority of Zimbabwe will handle those tenders submitted to it.

\section{Registration for authority to purchase}

The new act requires local governments to apply for registration and authorization to become procuring entities. Moreover, the registration is for a specified period, it has to be renewed after every two years. The third schedule of the act provides the punitive measures which will be imposed on and entity which fails to register and obtain authorization to purchase. However on the other hand, the act does not provide the timeframe which the Authority will respond to procuring entities. Further, the act does not offer guidance on what procuring entities must do in the event that the Authority fails to respond on the expected time.

This provision does not add any value to the enhancement of the procurement process as local governments have been procuring using the old procurement act. Introspection on this provision shows that this is just a bureaucratic way of concentrating power within the Procurement regulatory authority of Zimbabwe. If this was done to create a database, the Authority should have approached the Ministry responsible for Local Government, which has the names of all councils in the country. Local governments are statutory bodies with perpetual existence. Therefore there is no need to re-register them as it is very unlikely that they will liquidate. This provision shows that the new Authority has an appetite to remain relevant by remaining a focal referral point for all government agencies. To sum this up, it can be argued that the motive to reregister local governments by the Authority is driven by desire charge fees to procuring entities.

\section{Trainings and capacity development}

The development and enactment of a new legislation for procurement has been the desired outcome for public sector players for a long time. Therefore, in order for local government practitioners to grasp such a complex and sophisticated legislation, there was need for a clear and elaborate training plan to induct and orient people at all levels that implement and over sees procurement in rural local authorities by PRAZ. However, on the ground there has been few disjointed sensetisation one day workshops with different government departments. This approach does not equate to the seriousness of the new procurement act as it is a piecemeal approach to equipping practitioners. It is clear that trainings and capacity development was not given priority as evidenced from the workshop held for rural local authorities held in December 2018. Therefore,lack of knowledge can appear as if people are resisting implementing the new act.

\section{Institutional Capacity}

One key tenant of decentralization is the transfer of authority and responsibility; therefore it 
must be tied up with necessary resources which will enable implementation of policies. Resources include financial, human and technology to assist in the implementation of policies. The challenge of capacity in the rural district councils is a serious issues and it covers areas like that is financial resources, ICT skills and equipment. Through the Prime Ministers directive of 1984 this anomaly was noted and it was proposed that:

That central government, in implementing decentralisation, shall strengthen financial, human and material resource capacities of rural district councils to make them effective institutions in the provision of the social and infrastructural services needed for sustainable local development

However, this was never given serious consideration and as Chatiza (2013) noted policy makers, notably councillors, they have low levels of education which makes them unable to comprehend and interpret policy and legal issues. Furthermore, Chatiza ( 2013) noted that there is high labour turnover of professional employees because of unpredictable funding and poor human resources practices. In most cases the qualified staff members leave rural district councils to join urban councils which have better financial and other resources. This therefore, leaves rural district councils in most instances with unqualified staff and lowly-educated councillors, making it a serious challenge to interpret and implement legislation like the new public procurement act with the human capital in rural local authorities. For this reason, Chiappinelli (2017) concurred when he said that evidence from research showed that there is worse results if decentralized procurement does not come up with proper competencies. He further asserts that performance can be lower at the local level because of lower accountability and greater information asymmetries as well as administrative capacity and less well trained public officials.

In terms of financial capacities, rural district councils have poor a revenue base and weak financial systems and expenditure indiscipline (Chatiza, 2013). Coutinho (2010) reiterates this by pointing out that almost all local authorities had been facing insurmountable financial challenges due to poor financial accounting systems. Therefore, limited financial resources coupled with lack of capacity to train employees and policy makers place operational burden on rural councils. So, rural district councils are faced with financial challenges, which translates to incapacity to have professionals who would be able to implement the new procurement policy.

\section{E-procurement}

According to (Shakaya 2008) as cited by Sabiiti, (2017), e-procurement is:

The collaborative use of information and communications technology by government agencies and other actors of procurement community conducting activities of Government Procurement Process Cycle for the acquisition of goods, works and services and contract management ensuring good governance in the public procurement

Another school of thought defines e-procurement as the automation of an organization's procurement processes using web based applications, (Mohd Nasrun Mohd Nawi, et al 
(2016). From the above it can be deduced that e-procurement is the use of information technology that is computers, internet and other related software and hardware to purchase goods and services from vendors. E-procurement offers a vast array of advantages as it promotes efficiency, cost saving, transparency reduce corruption and streamlines activities. It simplifies regulations but makes every player still fully comply with the law thereby improving quality of services offered to the communities. In relations to public procurement, e-procurement eliminates some of the bureaucratic tendencies of having various layers found in the traditional procurement system thus giving confidence to all stakeholders who have interest in public procurement.

The Public Procurement and Disposal of Public Asset provides that all procuring entities should adopt e-procurement in order to improve on efficiency, cost saving and transparency. This development will improve the performance of rural district councils. In this regard, Jain, (2004) concurs that e-government can be used to reform or reinvent government due to its ability to enable collaboration and sharing of information among government bureaucracies thereby making them more responsive and efficient.

However, unlike their urban council counterparts, rural local authorities have serious ICT challenges that include adoption and utilization. The low uptake and utilization of ICT in Zimbabwe is an established culture in most public sectors even those who have everything at their disposal. This is evidenced by non-functional or static websites, use of personal emails for business and lack of investment in both hardware and software by departments. In terms of ICT infrastructure, rural district councils leg behind in having investment relating to infrastructure, as most of this is concentrated in urban settlements. This disparity has seen rural district councils legging behind in terms of connectivity. This means that adoption of e-procurement faces serious challenges. The same was echoed by Chatiza, (2013) who stated that adoption and penetration of ICT in rural district council is poor and in instances when it is available it is partially active in the accounts department only.

The other challenge in rural local authorities is limited information management skills by most of the top managers, notably Chief Executive Officers, Treasurers, Engineers and Human Resources practitioners. This further cascades to other employees in councils, thereby perpetuating a culture of relying on manual system which provides job security to individuals .Therefore, if leadership lacks ICT acumen, it means that they cannot push for ICT strategy because it will weaken them and expose their shortcoming. Whilst objective of the new act of adopting e- procurement is noble, there is need to provide necessary infrastructure to enable availability of internet in rural areas.

\section{Need for Collaboration with Institutions of Higher learning of Trainings}

Higher learning institutions have the propensity to alleviate skills shortage in local authorities. There is therefore need for strong collaboration with institutions of higher learning to teach public procurement in rural local authorities through short courses and specialised programmes at diploma and degree levels. This will facilitate the incorporation of mandatory public procurement modules to capacitate learners to appreciate both public procurement and private sector procurement. This approach is likely to produce graduates 
who easily integrate into the public sector.

\section{Human Resources: Recruitment}

In order to contain costs without compromising professionalism in procurement, rural local authorities need to employ at least one qualified employee. Through collaborations with institutions of higher learning, competent staff in councils will be continuously be capacitated and work under the supervision of the qualified procurement officer. This should be a continuous process to give adequate qualified staff will replace time of up to ten years as those without qualifications.

\section{Consolidating Returns}

In order to curtail most of the bureaucratic processes and paper work, the annual procurement return must be part and parcel of the external audit report as provided by the Public Finance Management Act. To achieve this, the Authority needs to engage the Auditor General such that when external auditors carry out their yearend audit they also cover the procurement using an agreed template. The external auditors report provides enough evidence which the Authority can base their opinion whether procurement procedures would have been followed or not. This streamlines work for councils as they will deal with one central government agency as compared to reporting to multiple agencies.

\section{Consolidating financial budget and Annual procurement Plan}

Local governments prepare annual financial budgets as per provisions of the rural district councils, chapter 29:13 which are approved by the Minister of Local Government. The financial budget is informed by items which the councils would instead procure in the subsequent year. It other words the financial budget is supported by the procurement budget. However, the current set up is that the financial budget is prepared using a different template whilst the procurement plan using another templet.Therefore, in order to avoid such burden, the Authority should have just provided a template which should be consolidated and submitted together with the annual financial budget to the Ministry of Local Government. The Authority will then get a copy of the report from the Ministry responsible for Local Governments.

\section{Decentralisation and devolution}

The Procurement Regulatory Authority of Zimbabwe must remain with its regulatory function and fully devolve all administrative procurement functions to rural local authorities. This entails disengaging itself in reviewing any tenders whatever the threshold. Local Governments are constitutional bodies established according to chapter 14 and section 276 assigns them powers to administer all its local affairs according to the dictates of the laws. As such, rural local authorities should prepare and approve their annual plans as they know what they intend to achieve. Procuring entities must not curtail their procurement by thresholds but must be able to handle all tenders regardless of amount involved and without any reference to the statutory body for approval. However, through the mandatory external audits, the Authority will then have to review the 
processes done by the local authorities. The Authority must extricate itself from such processes of reviewing of tenders that would have exceeded certain levels, as this will show commitment to the true spirit of decentralization.

\section{E-procurement}

It is recommended that before full adoption of electronic procurement, there is need the Government of Zimbabwe to work on connectivity and infrastructure in rural areas so that they could have easy access to computers and related gadgets. There must be a deliberate policy of capacity building for labour in councils to adopt, embrace and fully utilize information management systems in their daily activities.

\section{Implications of the Procurement on Service delivery}

Local governments are mandated to provide services to which have a bearing on socio-economic transformations of communities. This should be executed in a quick, efficient and effective way. The services range from roads, public lighting, refuse collection, educational infrastructure, health delivery, water and sanitation. The bulk of the material required to provide these services goes through a procurement process thereby bringing to the fore the need for an enabling legislation which is under friendly to local governments. In view of the above, the new procurement act add more bureaucratic layers, administrative paper work through several returns and reference to the Authority for permission to implement tenders. This affects the time span under which services will have to be delivered by local government officials. This therefore, result in unnecessary delays in implementing procurement decisions thereby negatively affecting service delivery.

\section{Conclusion}

The current public procurement and disposal of public assets act managed to achieve partial decentralization as there is a still remnant of the old procurement system in which major elements of procurement was centralized. The adoption of the procurement regime indicates that there was no extensive stakeholder consultation but it was hurriedly adopted without understating the critical differences between rural local authorities and other public sector organisations. The new act lacks the true spirit of devolution, as central government does not intend to relinquish administrative powers in terms of procurement to local governments. The change from the old State Procurement Board to Procurement Regulatory Authority of Zimbabwe can be equated to old wine in a new bottle, as the Authority is still intricately dictating the major procurement process.

Therefore, in order to fully comply with the tenets of decentralization there is need for amendment of the Act so that it takes into account the true events happening in rural local authorities in Zimbabwe.

\section{References}

Adewole, A. (2014). Governance Reform and the Challenge of Implementing Public Procurement Law Regime across Nigerian State and Local Governments. International Journal of Public Administration and Management Research, 25-32. 
Anthony, A. (2019). Re-Categorising Public Procurement in South Africa:Construction Works as a Special Case. Pioneer In Peer-Reviewed,Open Access Online Law Publications, 1-21. https://doi.org/10.17159/1727-3781/2019/v22i0a5270

Bland, N. L. (2010). Decentralization and Democratic Local Governance Programming Handbook. Center for Democracy And Governance, 1-80.

Bland, N. L. (2010). Decentralization and Democratic Localgovernance Programming Handbook.

Bolton, P. (2006). Government Procurement as A Policy Tool In South Africa. Journal Of Public Procurement, 193-217. https://doi.org/10.1108/JOPP-06-03-2006-B001

Chatiza, K. (2010). Can local government steer socio-economic transformation in Zimbabwe? Analyzing historical trends and gazing into the future. Community Law Centre, 1-37.

Chatiza, K. (2013). Capacity building for local governments and service delivery-Zimbabwe.Local Government capacity assessment report. Harare: Development Governance Institute.

Chiappinelli, O. (2017). Decentralization and Public Procurement Performance.New evidence from Italy. Germany Institute of Economic Research, 1-30.

Chigudu, D. (2014). Public Procurment In Zimbabwe: Issues and Challanges. Journal of Governance and Regulation, 1-5. https://doi.org/10.22495/jgr_v3_i4_p2

Coutinho, B. (2010). Sources of local government financing. In N. S. Jaap de Visser, Local government reform in Zimbabwe A policy dialogue (pp. 71-85). Western Cape: Community Law Centre.

Dennis, A., \& Rondinelli, J. R. (1983). Decentralization in Developing Countries A Review of Recent Experience. Washington, D.C: The World Bank.

Dennis, A., \& Rondinelli, J. R. (1983). Decentralization in Developing Countries,A Review of Recent Experience. World Bank Staff Working Papers, 581, 1-110.

Eisenhardt, K. (1989). Agency theory:An assessment and Review. Academy of Management Review, 57- 74. https://doi.org/10.5465/amr.1989.4279003

Faguet, J. (2012). Decentralization and Democracy. https://doi.org/10.3998/mpub.175269

Hartmann, G. C. (2008). Decentralization in Africa,A Pathway out of Poverty and Conflict? Amsterdam: Amsterdam University Press.

Jain, A. (2004). Using the lens of Max Weber's Theory of Bureaucracy to examine E-Government Research. Proceedings of the 37th Hawaii International Conference on System Sciences (pp. 1- 10). Temple University. https://doi.org/10.1109/HICSS.2004.1265321

Miti, P., \& Mapuva, J. (2019). Exploring the unchartered territory of devolution in Zimbabwe. Journal of African Studies and Development, 12-20. https://doi.org/10.25159/2663-6522/4932 


\section{$\triangle$ Macrothink}

Journal of Public Administration and Governance ISSN 2161-7104

Mohd Nasrum Mohd Nawi, S. R. (2016). The benefits and Challanges of E-procurment Implimentation: A Case Study of Malaysian Company. International Journal of Economics and Financial Issues, 329- 332.

Munzhedzi, P. H. (2016). South African public sector procurement and corruption: Inseparable twins? Journal of Transport and Supply Chain Management, 1-8. https://doi.org/10.4102/jtscm.v10i1.197

Musanzikwa, M. (2013). Public procurement system challenges in developing countries: the case of Zimbabwe. International Journal of Economics, Finance and Management Sciences, 119-127. https://doi.org/10.11648/j.ijefm.20130102.18

Mushamba, S. (2010). An Analysis of Powers And Functions Of Local Government Authorities In Zimbabwe. Community Law Centre, 1-44.

Olowu, D. (2009). Decentralization and Local Government in the Zimbabwean Constitution. Paper prepared for the Constitutional Conference, Raibow Towers, Zimbabwe, (pp. 1-20). Harare: Africa Europe Foundation, Netherlands.

Peters, B. G. (2000). Institutional Theory: Problems and Prospects. Vienna: University of Pittsburgh, Department of Political Science.

Reddy, P. S. (1997). Democratic decentralization and central/provincial/local relations in South Africa. International Journal of Public Sector Management, 572-588. https://doi.org/10.1108/09513559710193534

Sabiiti, C. K. (2017). E-Procurement Systems. 24th Esaag Annual International Conference (pp. 1-20). Johansburg: ESAAG.

Torfing, E. S. (2005). Network Governance and Post-Liberal Democracy. M.E. Sharpe, Inc., 197-237. Tsabora, J. (2014). African Procurment Law Journal, 1-21. https://doi.org/10.1080/10841806.2005.11029489

Tsabora, J. (2014). Public Procurment in Zimbabwe:Law,Policy and Practice. African Public Procurment Law Journal, 1-21. https://doi.org/10.14803/1-1-2

Wamalwa, J. K. (2018). Public Procurement in Kenya:Analysis of the Auditor General's Reports. Institute of Economic Affairs, 1-41.

Washington: USAID Center for Democracy and Governance Technical Publication Series.

Weiss, T. G. (2000). Governance, Good Governance and Global Governance: Conceptual and Actual Challenges. Taylor and Francis, 795-81 https://doi.org/10.1080/713701075

\section{Copyright Disclaimer}

Copyright for this article is retained by the author(s), with first publication rights granted to the journal.

This is an open-access article distributed under the terms and conditions of the Creative Commons Attribution license (http://creativecommons.org/licenses/by/4.0/). 